\title{
Hair chromium as an index of chromium exposure of tannery workers
}

\author{
JANIS A RANDALL, ROSALIND S GIBSON \\ From Applied Human Nutrition, Department of Family Studies, University of Guelph, Guelph, Ontario, Canada \\ NIG $2 W 1$
}

ABSTRACT The use of hair chromium $(\mathrm{Cr})$ concentrations as an index of $\mathrm{Cr}$ exposure of tannery workers was investigated. As has been shown earlier, $\mathrm{Cr}$ from $\mathrm{Cr}$ III compounds used in the leather tanning industry is absorbed because concentrations of $\mathrm{Cr}$ in serum and urine of tannery workers are significantly increased compared with corresponding concentrations for unexposed controls. Hair samples were collected from 71 male tannery workers from four southern Ontario tanneries and from 53 male controls not exposed to $\mathrm{Cr}$ in the workplace. Subjects were matched for age, race, and socioeconomic status. Hair samples were washed, ashed in a low temperature asher, and analysed by flameless atomic absorption. The median hair $\mathrm{Cr}$ concentrations for the tannery workers $(551 \mathrm{ng} / \mathrm{g})$ was significantly higher $(\mathrm{p}=0.0001)$ than for the controls $(123 \mathrm{ng} / \mathrm{g})$. For the tannery workers, hair Cr concentrations were positively and significantly correlated with serum $\operatorname{Cr}(r=0.52, p<0.01)$ and with the preshift and postshift urinary $\mathrm{Cr} /$ creatinine ratios $(\mathrm{r}=0.43, \mathrm{p}<0.01 ; \mathrm{r}=0.64, \mathrm{p}<0.01$, respectively). These data indicate that trivalent $\mathrm{Cr}$ absorbed from leather tanning compounds results in raised concentrations of $\mathrm{Cr}$ in hair and that hair $\mathrm{Cr}$ concentrations may be used as an index of industrial $\mathrm{Cr}$ exposure.

Data on the use of hair chromium $(\mathrm{Cr})$ concentrations in hair to monitor industrial exposure to $\mathrm{Cr}$ are limited. ${ }^{1}$ Nevertheless, the use of hair to monitor environmental exposure to lead, mercury, cadmium, and arsenic is well documented. ${ }^{2}$ Industrial exposure to $\mathrm{Cr}$ is usually monitored by analysis of air samples for total and hexavalent $\mathrm{Cr} .{ }^{3}$ Some investigators have also examined $\mathrm{Cr}$ concentrations in urine, ${ }^{4-9}$ whole blood, ${ }^{510}$ and serum/plasma, ${ }^{11}$ or red blood cells, or both, ${ }^{12}$ as indices of industrial exposure. Measurements of $\mathrm{Cr}$ in all these biological samples have the potential to screen for industrial $\mathrm{Cr}$ exposure before the possible development of adverse health effects. Routine $\mathrm{Cr}$ analysis of such biological samples is difficult, however, because they normally contain concentrations of $\mathrm{Cr}$ that are less than $1 \mathrm{ppb}$, values well below the limits of detection for many analytical systems. By contrast, physiological concentrations of $\mathrm{Cr}$ in hair are up to 1000 times higher than those in the serum and urine, thus facilitating analysis. Hence, the

Presented in part at the $\mathrm{VI}^{\text {th }}$ Symposium on Trace Elements in Man and Animals, Monterey, California, May 1987.

Accepted 29 February 1988 use of hair as a biopsy material for monitoring industrial exposure to $\mathrm{Cr}$ warrants further study.

We have investigated the use of hair $\mathrm{Cr}$ concentrations as an index of industrial exposure to trivalent $\mathrm{Cr}$. We examined the relations between $\mathrm{Cr}$ concentrations in hair and corresponding $\mathrm{Cr}$ concentrations in the serum and urine of tannery workers exposed to industrial trivalent $\mathrm{Cr}$ and those unexposed to $\mathrm{Cr}$ in the workplace.

\section{Methods}

Details of the subjects recruited for this study have been published earlier. ${ }^{13}$ Samples were collected on a voluntary basis from 71 male tannery workers (mean age $\pm \mathrm{SD}=38 \pm 11$ years) from four southern Ontario tanneries and from 53 control subjects $(40 \pm$ 13 years) from the Guelph and Toronto areas. Subjects were matched for age, race, sex, and socioeconomic status. A questionnaire that included demographic and health data was completed by each subject. None of the subjects in this study had a history of coronary heart disease or of insulin or non-insulin dependent diabetes. Information on brands of shampoo and on the use of hair beauty treatments was also obtained. 
None of the subjects used bleaches, hair dyes, or other hair beauty treatments. The study was approved by the human ethics committee of the University of Guelph.

A small portion of hair (100-200 mg) was cut from the suboccipital portion of the scalp and the proximal $1.5 \mathrm{~cm}$ was placed in a plastic bag for later analysis. Hair samples were washed according to the method of Kumpulainen et al. ${ }^{14}$ The samples were rinsed with hexane, washed twice with $1 \%$ sodium lauryl sulphate solution, and subsequently rinsed six times in distilled deionised water. Wet hair samples were dried at $105^{\circ} \mathrm{C}$ in acid washed quartz glass boats to constant weight and then ashed in a low temperature asher (LTA 504, LFE Corporation, Waltham, MA) for 12-16 hours. The ash was dissolved in $4 \mathrm{ml}$ of $0.1 \mathrm{~N} \mathrm{HCl}$ (GFS Chemical Co, Cincinnati, $\mathrm{OH}$ ) and subsequently analysed for $\mathrm{Cr}$ by flameless atomic absorption spectrophotometry (Varian Spectra 30, GTA 96 Furnace, Georgetown, Ontario).

Accuracy of the analytical method was checked by ashing and analysing a reference hair material, certified for $\mathrm{Cr}$ content. ${ }^{15}$ The mean $\pm \mathrm{SD}(\mathrm{n}=10)$ was $1.3 \pm 0.2 \mu \mathrm{g} / \mathrm{g}$ compared with the certified value of 1.4 $\pm 0.2 \mu \mathrm{g} / \mathrm{g}$. A pooled hair sample $(\mathrm{n}=68)$ was also ashed and analysed in each run to check on the precision of the analysis. The mean \pm SD of the pooled samples was $174 \pm 29 \mathrm{ng} / \mathrm{g}$. In addition, a pooled ashed hair sampled was analysed several times during each GFAAS analysis to check on the precision of the spectrophotometric analysis. Coefficients of variation within and between runs were $6 \%$ and $8 \%$, respectively.

Area air samples were collected from three work areas in each tannery for three days as described previously. ${ }^{13}$ Total air $\mathrm{Cr}$ concentrations were determined by flame atomic absorption spectrophotometry according to the method outlined by the National Institution for Occupational Safety and Health. ${ }^{3}$

Fasted blood samples were collected from each subject in the sitting position and the serum was harvested. Spot urine samples were collected from each subject on a Friday afternoon (postshift). In addition, spot urine samples were collected from the tannery workers on the following Monday morning (preshift). Serum and urinary $\mathrm{Cr}$ concentrations were determined and have been reported previously. ${ }^{13}$

The hair $\mathrm{Cr}$ concentrations in the tannery workers and the control group were not normally distributed, therefore non-parametric statistics were used. The median was used to indicate central tendency and the first and third quartiles were used to measure dispersion. The Kruskal-Wallis test was used to test for differences in median hair $\mathrm{Cr}$ concentrations between the tannery workers and the control subjects. The Spearman rank correlation coefficient was used to test for correlations between $\mathrm{Cr}$ concentrations in hair and $\frac{\pi}{2}$ corresponding values in serum and urine.

\section{Results}

The median hair $\mathrm{Cr}$ concentration for the tannery $\frac{\overline{ }}{\overline{0}}$ workers was significantly higher $(p=0.0001)$ than $\frac{\widehat{D}}{\widehat{D}}$ that of the controls (table). Median hair chromium concentrations in tannery workers and
controls

\begin{tabular}{lllll}
\hline & $\begin{array}{l}\text { Tannery } \\
\text { workers } \\
(n=71)\end{array}$ & $\begin{array}{l}\text { Control } \\
\text { subjects } \\
(n=53)\end{array}$ & $p^{*}$ & \\
\hline $\begin{array}{l}\text { Hair Cr } \\
(\mathrm{ng} / \mathrm{g}) \dagger\end{array}$ & $\begin{array}{l}551 \\
(310-1083)\end{array}$ & $\begin{array}{l}123 \\
(79-199)\end{array}$ & 0.0001 \\
\hline
\end{tabular}

*Kruskal-Wallis test.

†1st-3rd quartiles.

Hair $\mathrm{Cr}$ concentrations for the tannery workers? were significantly and positively correlated with corre- 3 sponding concentrations of serum $\mathrm{Cr}(\mathrm{r}=0.52, \mathrm{p}=$ $0.0001)$, postshift urinary $\mathrm{Cr}(\mathrm{r}=0.71, \mathrm{p}=0.0001)$, and with the postshift urinary $\mathrm{Cr} / \mathrm{Cre}$ ratios $(\mathrm{r}=0.64, \overrightarrow{\mathrm{c}}$ $\mathrm{p}=0.0001$ ) (fig 1). The preshift urinary $\mathrm{Cr}$ concentrations and the $\mathrm{Cr} / \mathrm{Cre}$ ratios were also correlated with hair $\mathrm{Cr}$ concentrations $(r=0.45, p=0.003 ; r=0.43$, $p=0.005$, respectively). Such relations were not found for the controls.

Hair $\mathrm{Cr}$ concentrations were also associated with $\frac{0}{\varnothing}$ the area of employment but not with duration of $\cong$ employment in the tanning industry. The median hair $\overrightarrow{\overrightarrow{0}}$ $\mathrm{Cr}$ concentration was significantly higher for workers 3 handling wet hides in the chrome tan and wringing departments than for workers in other areas of the tanneries (fig 2a). Total air $\mathrm{Cr}$ concentrations did not ${ }^{\circ}$ significantly differ among work areas of the tanneries 3 (fig 2b).

Hair $\mathrm{Cr}$ concentrations were not correlated with age, height, or weight in either group.

\section{Discussion}

The results of this study suggest that hair $\mathrm{Cr}$ concentrations may be used as indices of industrial exposure to trivalent $\mathbf{C r}$. For instance, tannery workers exposed $\mathrm{Gr}$ to trivalent $\mathrm{Cr}$ had significantly higher median $\mathrm{Cr} N$ concentrations in hair compared with unexposed controls. Concentrations of $\mathrm{Cr}$ in hair were associated with the area of work in the tannery.

To confirm the validity of hair $\mathrm{Cr}$ concentrations as a biological index of industrial $\mathrm{Cr}$ exposure, the $\stackrel{\rho}{+}$ relation between $\mathrm{Cr}$ concentrations in hair and body $\mathrm{O}$ burden of $\mathrm{Cr}$ must be established. ${ }^{16}{ }^{17} \mathrm{At}$ present, ${ }^{\circ}$ comparable data exist for mercury, arsenic, and lead $\stackrel{\odot}{\AA}$ but not for $\mathrm{Cr}^{2}{ }^{17}$ Nevertheless, the significant positive $\stackrel{\mathbb{Q}}{\mathscr{Q}}$ 
(a)
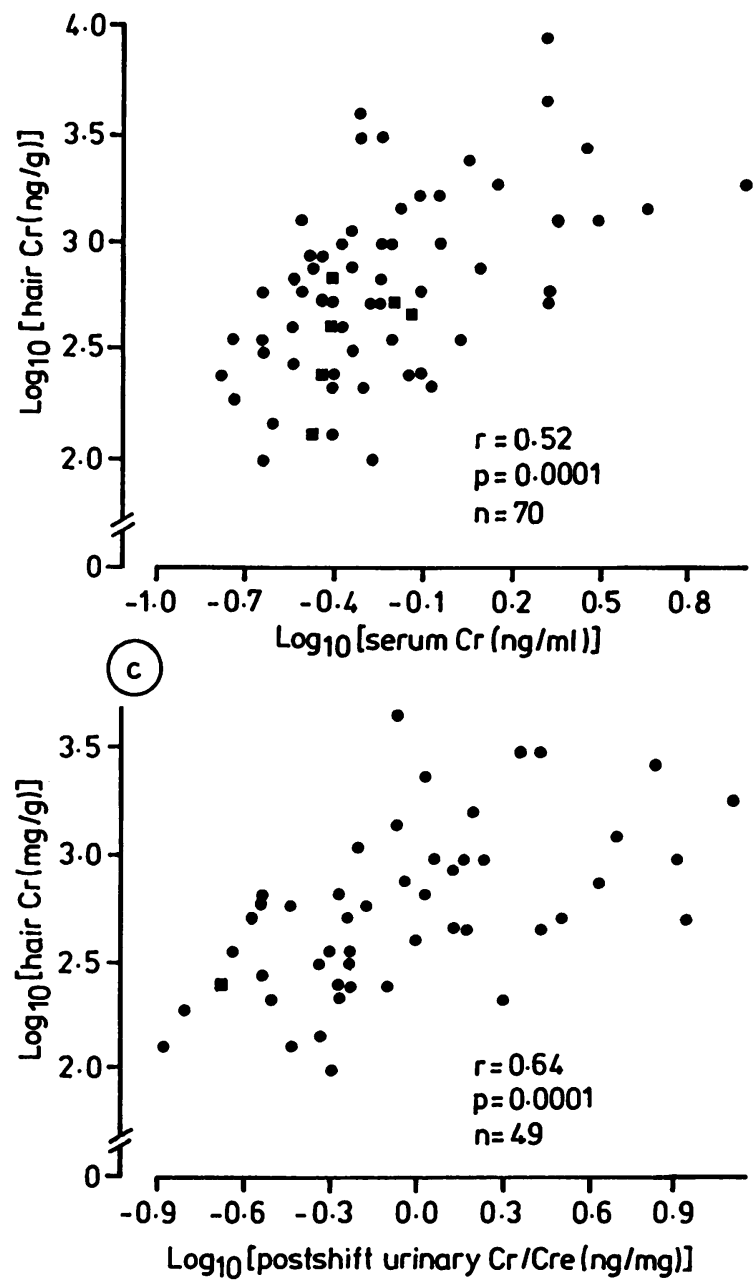

(b)

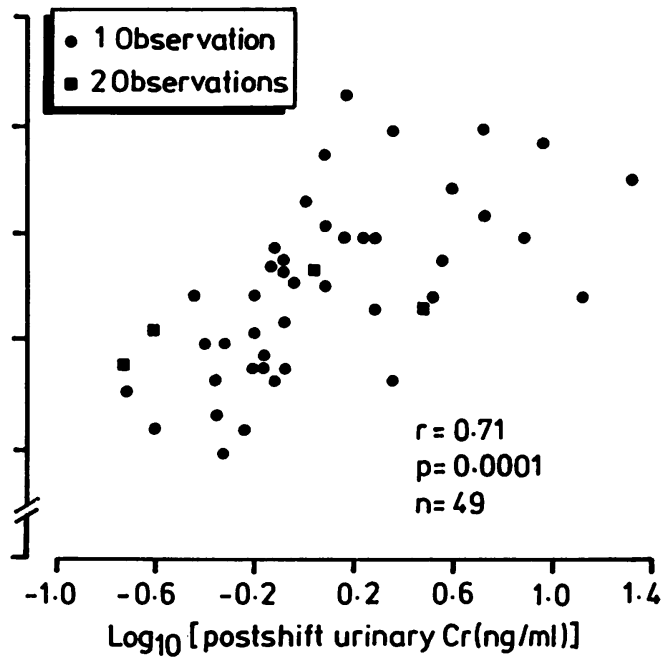

Fig 1 Scatter plot of $\log _{10}$ hair chromium concentrations and (a) $\log _{10}$ serum chromium concentrations. (b) $\log _{10}$ postshift urinary chromium concentrations, and (c) $\log _{10}$ postshift urinary $\mathrm{Cr} /$ Cre ratios. correlations observed here among three independent indices of $\mathrm{Cr}$ exposure for the tannery workers (concentrations of $\mathrm{Cr}$ in hair, serum, and urine) indicate that hair is a valid measure of industrial exposure to $\mathrm{Cr}$.

There are several advantages of using hair analysis to assess industrial exposure to $\mathrm{Cr}$ compared with the analysis of $\mathrm{Cr}$ in serum or urine. No special equipment is required for collecting or storing hair for $\mathrm{Cr}$ analysis, whereas trace element free equipment and clean room conditions are essential for collecting serum and urine. ${ }^{18}$ Indeed, the wide range ( 1000 -fold) of physiological $\mathrm{Cr}$ concentrations reported for serum and urine compared with hair ${ }^{1819}$ may arise in part from failure to include such precautions. In addition, $\mathrm{Cr}$ concentrations in hair are much higher than those in serum or urine so that accuracy and precision during analysis are more easily achieved.

Any exogenous contamination must be removed by a standardised washing procedure before hair $\mathrm{Cr}$ concentrations may be used as an index of industrial exposure to $\mathrm{Cr}$. Several washing methods for hair analysis have been described. ${ }^{142021}$ The results of this study suggest that the washing procedure of Kumpulainen et al, used here, effectively removed any exogenous $\mathrm{Cr}$ contamination from the hair of the tannery workers. ${ }^{14}$ Positive correlations were noted between the hair $\mathrm{Cr}$ concentrations and corresponding serum and urine $\mathrm{Cr}$ concentrations. Saner et al also observed a significant positive correlation between hair $\mathrm{Cr}$ concentrations and urinary $\mathrm{Cr} / \mathrm{Cre}$ ratios in Turkish tannery workers.' 

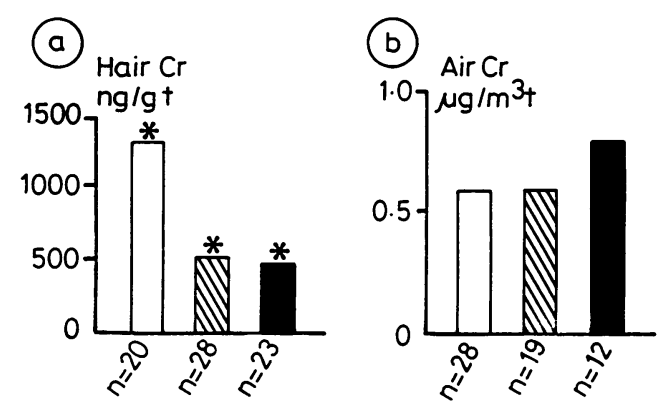

$\square$ Chrome tan, wringing departments
BV Blue sort, split and shave, buffing dust
Upper leather finish, plant services, supervisors
* $p<0.05+$ Median

Fig 2 (a and b) Total air chromium concentrations and hair chromium concentrations in three work areas of tanneries.

Biological monitoring for industrial $\mathrm{Cr}$ is not routinely performed, especially if the exposure is to trivalent $\mathrm{Cr}$ which is considered to be poorly absorbed. ${ }^{22}$ Instead, concentrations of total $\mathrm{Cr}$ and $\mathrm{Cr} \mathrm{VI}$ in air samples are conventionally measured. This approach can, however, produce misleading results. For example, in our study total and hexavalent air $\mathrm{Cr}$ concentrations in all areas of the tanneries studied were well below the maximum allowable time weighted average exposure as proposed by the Ontario Ministry of Labour. ${ }^{23}$ Concentrations of $\mathrm{Cr}$ in hair, serum, and urine, however, were considerably raised, especially in those tannery workers working in the chrome tan and wringing departments. These results are not surprising because the $\mathrm{Cr}$ content of these biological samples represents that which is absorbed not only through the respiratory tract but also through the skin and the gastrointestinal tract. Other investigators have also reported no correlation between air $\mathrm{Cr}$ (total and $\mathrm{Cr} \mathrm{VI}$ ) and urinary $\mathrm{Cr}$ in workers exposed to $\mathrm{Cr} \mathrm{VI}^{1124}$ and $\mathrm{Cr}$ III. ${ }^{25}{ }^{26}$ Hence, our findings indicate that trivalent $\mathrm{Cr}$ was indeed absorbed by the tannery workers and emphasise the importance of biological monitoring.

The absence of any significant correlations between hair $\mathrm{Cr}$ concentrations and those of serum $\mathrm{Cr}$, urinary $\mathrm{Cr}$, or urinary $\mathrm{Cr} / \mathrm{Cre}$ ratios for the controls is not unexpected. Other investigators have failed to observe consistent correlations in normal unexposed individuals between hair trace element concentrations and corresponding concentrations in other tissues, fluids, or organs. " To our knowledge, no comparable data for $\mathrm{Cr}$ exist at present.
The cooperation of the Tanners' Association of Canada and the managements of the four tanneries.. was much appreciated.

This work was supported by the Ontario Ministry of Labour.

\section{References}

1 Saner G, Yuzbasiyan V, Cigdem S. Hair chromium concentration and chromium excretion in tannery workers. $\mathrm{Br} J$ Ind $\mathrm{Med}_{\vec{O}}$ 1984;41:263-6.

2 Creason JP, Hinners TA, Bumgarner JE, Pinkerton C. Trace -1 elements in hair, as related to exposure in metropolitan New York. Clin Chem 1975;21:603-12.

3 National Institution for Occupational Safety and Health. NIOSH零 manual of analytical methods, 3rd ed. Cincinnati: NIOSH, 1984.7.

4 Glyseth B, Gundersen N, Langard S. Evaluation of chromium $\vec{\sigma}$ exposure based on a simplified method for urinary chromium determination. Scand J Work Environ Health 1977;3:28-31.

5 Tola S, Kilpio J, Vertamo M, Haapa K. Urinary chromium as an indicator of welders to chromium. Scand $J$ Work Environ Health 1977;3:192-202.

6 Mutti A, Cavatorta A, Pedroni C, Borghi A, Giaroli C, FranchiniI. The role of chromium accumulation in the relationship $\bar{Z}$ between airborne and urinary chromium in welders. Int Arch Occup Environ Health 1979;43:123-33.

7 Lindberg E, Vesterberg 0 . Monitoring exposure to chromic acid in chromeplating by measuring chromium in urine. Scand J Work $\overrightarrow{0}$ Environ Health 1983;9:333-40.

8 Sjogren B, Hedstrom L, Ulfvarson U. Urine chromium as an estimator of air exposure to stainless steel welding fumes. Int Arch Occup Environ Health 1983;51:347-54.

9 Welinder H, Littorin M, Gullberg B, Skerfving S. Elimination of chromium in urine after stainless steel welding. Scand J Work Environ Health 1983;9:397-403.

10 Ulfvarson U, Wold S. Trace-element concentrations in blood samples from welders of stainless steel or aluminium and reference group. Scand J Work Environ Health 1977;3:183-91. 음

11 Rahkonen E, Junttila ML, Kalliomaki PL, Olkinoura M, Koponen M, Kalliomaki R. Evaluation of biological monitoring among stainless steel welders. Int Arch Occup Environ Healt to. 1983;52:243-55.

12 Lewalter J, Korallus U, Harzdorf C, Weidemann H. Chromium bond detection in isolated erythrocytes: a new principle of biological monitoring of exposure to hexavalent chromium. Inio Arch Occup Environ Health 1983;55:305-18.

13 Randall JA, Gibson RS. Serum and urine chromium as indices of chromium status in tannery workers. Proc Soc Exp Biol Med 1987;185:16-23.

14 Kumpulainen J, Lehto J, Koivistoinen P. Determination of chromium in human milk, serum and urine by electrothermaP atomic absorption spectrometry without preliminary ashing $\frac{D}{O}$ Sci Total Environ 1983;31:71-80.

15 Okamoto K, Morita M, Quan H, Uehiro T, Fuwa K. Preparation and certification of human hair powder reference material. Cling Chem 1985;31:1592-7.

16 Korallus U. Chromium compounds: occupational health, toxicological and biological monitoring aspects. In: Toxicological and environmental chemistry. London: Gordon and Breach 1986:47-59.

17 Taylor A. Usefulness of measurements of trace elements in hair Ann Clin Biochem 1986;23:364-78.

18 Borel JS, Anderson RA. Chromium. In: Frieden E, ed. Biochemis try of the essential ultratrace elements. New York: Plenum, $\square$ 1984:175-99.

19 Shapcott D, Vobecky JS, Demers PP, Vobecky J, Cote M. Hairึ analysis for the detection of chromium deficiency. In: Howe? $\mathrm{JMcC}$, ed. Trace element metabolism in man and animals 
Proceedings of the 4th International Symposium, Perth, 1981. Berlin: Springer-Verlag, 1981:397-9.

20 Hambidge KM, Franklin ML, Jacobs MA. Hair chromium concentration: effects of sample washing and external environment. Am J Clin Nutr 1972;25:384-9.

21 Salmela S, Vuori E, Kilpio J. The effect of washing procedures on trace element content of human hair. Anal Chim Acta 1981;125: 131-7.

22 Anderson RA, Polansky MM, Bryden NA, Patterson KY, Veillon C, Glinsmann W. Effects of chromium supplementation on urinary chromium excretion of human subjects and correlation of chromium excretion with selected clinical parameters. $J$ Nutr 1983;113:276-91.

23 Ontario Ministry of Labour, Occupational Health and Safety
Division. Proposed regulation respecting chromium-made under the occupational health and safety act. Toronto: Ontario Ministry of Labour, 1986.

24 Guillemin MP, Berode M. A study of the difference in chromium exposure in workers in two types of electroplating process. Ann Occup Hyg 1978;21:105-12.

25 Kiilunen M, Kivisto H, Ala-Kaurila P, Tossavainen A, Aitio A. Exceptional pharmokinetics of trivalent chromium during occupational exposure to chromium lignosulfonate dust. Scand $J$ Work Environ Health 1983;9:265-71.

26 Aitio A, Jarvisalo J, Kiilunen M, Tossavainen A, Vaittinen P. Urinary excretion of chromium as an indicator of exposure to trivalent chromium sulphate in leather tanning. Int Arch Occup Environ Health 1984;54:241-9.

\section{Vancouver style}

All manuscripts submitted to the $B r J$ Ind Med should conform to the uniform requirements for manuscripts submitted to biomedical journals (known as the Vancouver style)

The $\mathrm{Br} J$ Ind Med, together with many other international biomedical journals, has agreed to accept articles prepared in accordance with the Vancouver style. The style (described in full in $\mathrm{Br}$ Med J, 24 February 1979, p 532) is intended to standardise requirements for authors.

References should be numbered consecutively in the order in which they are first mentioned in the text by Arabic numerals above the line on each occasion the reference is cited (Manson ${ }^{1}$ confirmed other reports ${ }^{2-5} \ldots$.). In future references to papers submitted to the $\mathrm{Br} J$ Ind Med should include: the names of all authors if there are six or less or, if there are more, the first three followed by et al; the title of journal articles or book chapters; the titles of journals abbreviated according to the style of Index Medicus; and the first and final page numbers of the article or chapter.

Examples of common forms of references are:

1 International Steering Committee of Medical Editors. Uniform requirements for manuscripts submitted to biomedical journals. Br Med J 1979;1:532-5.

2 Soter NA, Wasserman SI, Austen KF. Cold urticaria: release into the circulation of histamine and eosino-phil chemotactic factor of anaphylaxis during cold challenge. $N$ Engl J Med 1976;294:687-90.

3 Weinstein L, Swartz MN. Pathogenic properties of invading micro-organisms. In: Sodeman WA Jr, Sodeman WA, eds. Pathologic physiology: mechanisms of disease. Philadelphia: W B Saunders, 1974:457-72. 